\title{
Short Communication: Sarocladium oryzae associated with sheath rot disease of rice in Indonesia
}

\author{
SYAFIQA PRAMUNADIPTA ${ }^{1, \bullet}$, ANI WIDIASTUTI ${ }^{2}$, ARIF WIBOWO ${ }^{2}$, HARUHISA SUGA ${ }^{3}$, \\ ACHMADI PRIYATMOJO ${ }^{2, \bullet \varphi}$ \\ ${ }^{1}$ Graduate Program in Agricultural Science, Faculty of Agriculture, Universitas Gadjah Mada. Kampus UGM Bulaksumur, Sleman 55281, Yogyakarta, \\ Indonesia. `email: syafiqapramuna@gmail.com \\ ${ }^{2}$ Departement of Crop Protection, Faculty of Agriculture, Universitas Gadjah Mada. Jl. Flora No. 1, Bulaksumur, Sleman 55281, Yogyakarta, Indonesia. \\ Tel./fax.: +62-274-523926. " "email: priyatmojo@ugm.ac.id. \\ ${ }^{3}$ Life Science Research Center, Gifu University. 1-1 Yanagido, Gifu 501-1193, Japan
}

Manuscript received: 9 December 2019. Revision accepted: 27 February 2020.

\begin{abstract}
Pramunadipta S, Widiastuti A, Wibowo A, Suga H, Priyatmojo A. 2020. Short Communication: Sarocladium oryzae associated with sheath rot disease of rice in Indonesia. Biodiversitas 21: 1243-1249. One of the obstacles in increasing rice production is the presence of sheath rot pathogen infection, which causes changes in color on the rice sheath to brown or reddish-brown, sometimes does not produce rice grain. The major fungal pathogens that cause sheath rot disease are Sarocladium oryzae and Fusarium spp. The loss of rice yields reaches $85 \%$. The disease found in six provinces, some of which are the largest rice-producing centers in Indonesia. A total of twenty-four Sarocladium sp. were isolated from leaf sheath symptom on potato dextrose agar and water agar medium. Sheath rot pathogen identification based on molecular method was performed using internal transcribed spacer (ITS) rDNA gene sequencing. Necrosis occurs after artificial inoculation in Ciherang rice variety was observed and showed that all isolates were pathogenic. Morphological characterization of the isolates identified them as Sarocladium sp. Molecular identification showed that six representatives isolates belonging to $S$. oryzae. These findings are important information about the fungal pathogen that causes sheath rot disease in Indonesia, and in studies for formulating control measures of the pathogen in the future to prevent the disease epidemic on rice. This is the first report about the existence of sheath rot disease, morphological characterization and molecular identification of $S$. oryzae in various rice fields in Indonesia.
\end{abstract}

Keywords: Gene sequencing, ITS rDNA, rice, Sarocladium, sheath rot disease

\section{INTRODUCTION}

Rice (Oryza sativa L.) is the most important product of agriculture in Indonesia (Mau et al. 2017). In 2019, provinces in Indonesia, which have the largest rice production were Central Java, East Java, West Java and South Sulawesi (BPS 2020). The human need for rice always increases from year to year in line with the increase in population. Sheath rot disease possible to become an obstacle in efforts to increase rice productivity (Garcia et al. 2003; Shamsi and Chowdhury 2016). The main pathogens associated with this disease in some countries are fungal pathogens such as Sarocladium oryzae and Fusarium spp. that can spread by wind and seed and the bacterial pathogen such as Pseudomonas fuscovaginae (Bigirimana et al. 2015). These pathogens produce very similar symptoms.

Sarocladium oryzae was known to be the first major important pathogen of fungi that caused sheath rot disease of rice after been first isolated in 1922 in Taiwan (Mathur 1981; Mew and Gonzales 2002; Ayyadurai et al. 2005; Bigirimana et al. 2015). S. oryzae also is known to produce antimicrobial secondary metabolites such as helvolic acid and cerulenin (Bridge et al. 1989; Tschen et al. 1997; Ghosh et al. 2002; Hittalmani et al. 2016). S. oryzae develops well in rain-fed rice fields, and found in lowland and medium land environments (Pearce et al. 2001; Sarangi et al. 2019). Sheath rot disease symptom usually occurs on the leaf sheath which encloses panicles on rice plants. The infected leaf sheath will rot, turn grayish-brown or reddishbrown spot depending on rice cultivars and sometimes produce no grain of rice (Nair 1976; Ou 1985; Mvuyekure et al. 2017). The brown spot has a length of $0.5-1 \mathrm{~cm}$ and width of 0.2 to $0.5 \mathrm{~cm}$, while the healthy sheath remains green (Amin et al. 1974). The disease spots are linear, have irregular margins and at the next stage, the disease spot will unite and cover the entire sheath (Srinivasachary et al. 2002). Pathogens that infect leaf sheath make the young panicles cannot get out of the leaf sheath and solidify or partly appear but produce empty, partly filled and turn into brown (Mvuyekure et al. 2017). The losses incurred were in the form of quantitative losses (loss of yields including discoloration of grain becomes unsuitable for sale) and qualitative losses (Gopalakrishnan et al. 2010; Zhang et al. 2019). Rice sheath rot causes yield losses that vary from $20 \%$ to $85 \%$ (Desjardins et al. 2000; Sakthivel 2001; Park et al. 2005; Balgude et al. 2019).

Moreover, it is important to understand the impact of the yield loss because of the infection of sheath rot disease, to formulating a method on how to control the disease on 
future research. The pathogens that associated with sheath rot disease have not yet reported in Indonesia. Hence, this study will be conducted to generate information about the existence of $S$. oryzae in several rice fields in Indonesia, the pathogenicity and cultural characters of the pathogens through field survey, pathogenicity test, morphological characterization and ITS rDNA gene sequencing.

\section{MATERIALS AND METHODS}

\section{Study area}

Sheath rot disease samples were collected by purposive sampling in various varieties from several rice fields in six provinces in Indonesia including Banten, West Java, Central Java, East Java, Bali and South Sulawesi (Figure 1). Banten and Bali provinces were chosen as comparison regions from other provinces that had the largest rice production. The symptoms in the leaf sheath were cut from each rice tiller, then put in a paper bag, and stored in a cooler box before isolation process.

\section{Procedures}

Isolation of Sarocladium sp.

Isolation process was carried out by Chowdhury et al. (2015) with modification, the area between infected and healthy tissue was cut into small pieces (approx. $5 \mathrm{~mm}^{2}$ ), then sterilized with $1 \%$ sodium hypochlorite for $2 \mathrm{~min}$, rinsed once with sterile water for $2 \mathrm{~min}$, and dried up on sterile filter paper. The leaf sections were placed on PDA (Potato Dextrose Agar for microbiology, Millipore Sigma 110130 ) plates and incubated at $25^{\circ} \mathrm{C}$ for $5-7 \mathrm{~d}$ to observed fungal growth (Gnanamanickam and Mew 1991). Single spore of Sarocladium sp. were maintained on water agar (WA) (WA; agar, 20g; water to final volume of $1.000 \mathrm{ml}$ ) plates, then incubated in the dark at $25^{\circ} \mathrm{C}$ for $12 \mathrm{~h}$ to permit conidial germination. The germinate fungal spore then identified by examination through a light microscope and transferred into new PDA plates.

\section{Pathogenicity test}

Ciherang rice variety aged eight weeks after transplanting was used for artificial inoculation with single rice grain that colonized by Sarocladium sp. in $7 \mathrm{~d}$. The colonized of single rice grain, then inoculated on the leaf sheath of three rice tillers in each three clumps without wounding. The control of plant inoculated by single rice grain without colonizing by fungi. Then, rice sheath covered with cotton, soaked in sterile water and left overnight. The next day, the cotton was removed. The inoculated rice was placed under controlled greenhouse conditions. The symptoms were observed every day to note the time initial symptoms appear, and disease severity index (DSI; Narayanasamy and Viswanathan 1990) until the harvest period. Sarocladium sp. was re-isolated using PDA plates, and confirmed with inoculated isolates.

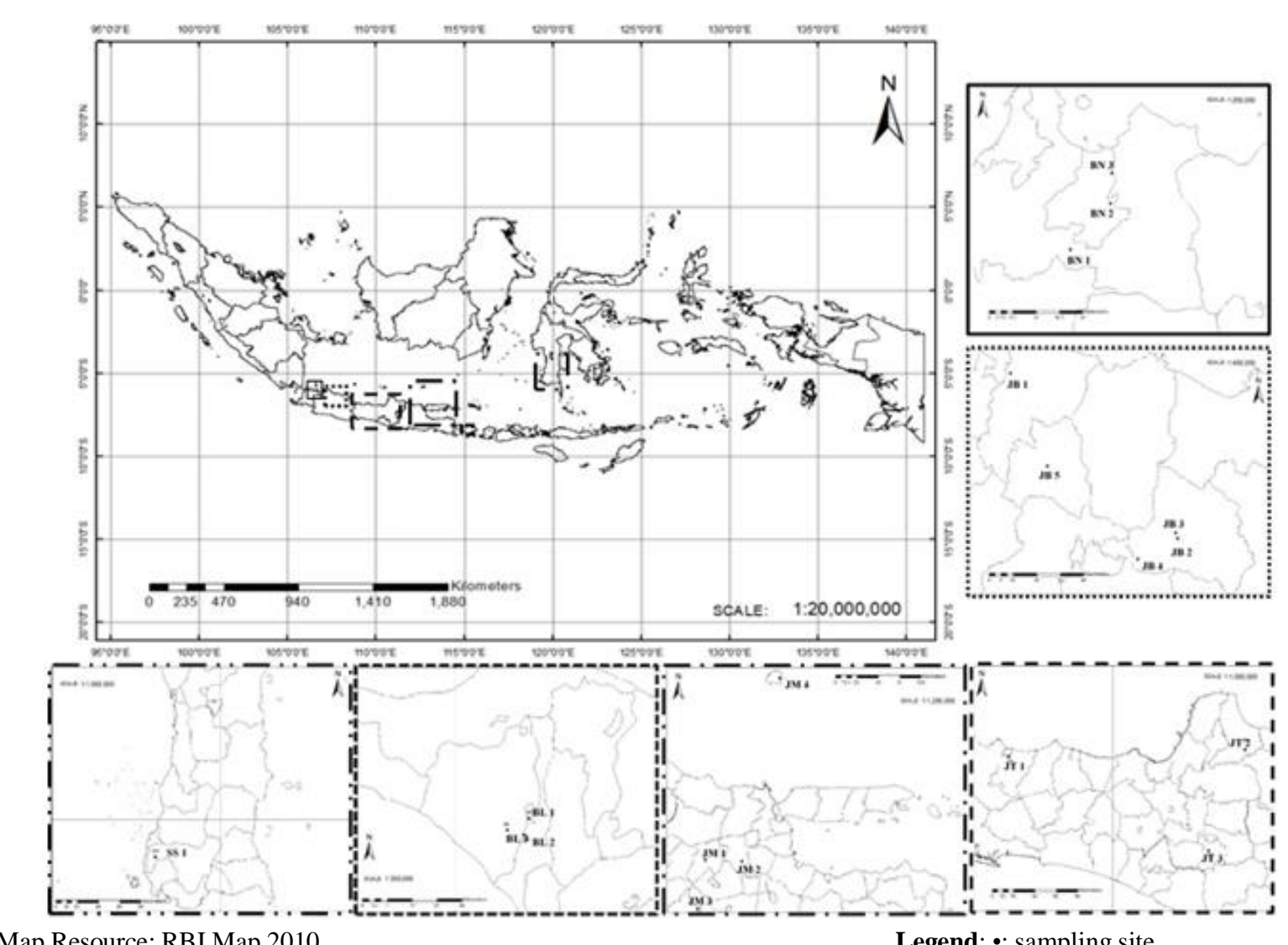

Map Resource: RBI Map 2010

Legend: $\bullet$ : sampling site

Figure 1. Sampling sites for the location of sheath rot disease from several rice fields 


\section{Culture morphology characteristics}

The morphological characteristics of the isolates were studied based on culture growth on PDA were incubated at $25^{\circ} \mathrm{C}$ in the dark and examined each $7 \mathrm{~d}$ up to 4 weeks (Giraldo et al. 2015; Liu et al. 2017). Fungal colony colors determined using the color charts by Kornerup and Wanscher (1978). Microscopic features were examined by slide cultures on oatmeal agar (OA) (OA; filtered oat flakes after $1 \mathrm{~h}$ of simmering, $30 \mathrm{~g}$; agar, $20 \mathrm{~g}$; water to final volume of $1.000 \mathrm{ml}$ ) (Giraldo et al. 2015). Fifty conidia were observed for shape and size measures. The examination was done using Olympus CX21 Binocular Microscope, images captured by OptiLab Microscope Camera and Optilab viewer 2.2 software. Conidia measured by Image Raster 3.0 software. Sarocladium sp. was identified from cultures grown on PDA plates, according to the descriptions of Giraldo et al. (2015).

\section{DNA extraction, amplification, and sequencing}

Representative isolates were selected for molecular identification. Isolates were grown on potato dextrose broth (PDB) (PDB; potato 200g; dextrose 20g; water to final volume of $1.000 \mathrm{ml}$ ) for $3-4 \mathrm{~d}$ at $25^{\circ} \mathrm{C}$ by using potassium ethyl xanthogenate solution, as previously described (Suga et al. 2008). The final DNA pellet was dissolved in $400 \mu \mathrm{L}$ of water. The ITS rDNA region was amplified with the primer pairs ITS1/ITS4 (White et al. 1990). Reactions were performed in BioRad T100 ${ }^{\mathrm{TM}}$ Thermal Cycler using the following conditions: initial denaturation at $94^{\circ} \mathrm{C}$ for $2 \mathrm{~min}$, 30 cycles of denaturation at $94^{\circ} \mathrm{C}$ for $1 \mathrm{~min}$, annealing at $55^{\circ} \mathrm{C}$ for $1 \mathrm{~min}$, extension at $72^{\circ} \mathrm{C}$ for $2 \mathrm{~min}$, final extension at $72^{\circ} \mathrm{C}$ for $7 \mathrm{~min}$, followed by stored at $4^{\circ} \mathrm{C}$. PCR products were directly sequenced as previously described (Suga et al. 2008). The sequence was obtained by an ABI 3100 genetic analyzer (Life Technologies).

\section{Alignment and phylogenetic analysis}

The results of the ITS rDNA gene sequence were then compared with sequences in the GenBank were performed in Nucleotide Basic Local Alignment Search Tool (BLASTn) (https://blast.ncbi.nlm.nih.gov/Blast.cgi). Sequences were assembled and manually edited in MEGAX. Maximum-likelihood (ML) analysis was implemented in MEGAX software (Kumar et al. 2018) with 1000 bootstrap replications and GTR+G+I model. Reference sequences retrieved from the BLASTn search based on ITS rDNA gene sequences (Bills et al. 2004; Giraldo et al. 2015) were used for phylogenetic analysis (Table 2; Figure 4). The outgroup of phylogenetic tree using Acremonium curvulum that not include in the Sarocladium clade but closely related to Sarocladium sp. (Giraldo et al. 2012). The phylogenetic tree was visualized using FigTree (http://tree.bio.ed.ac.uk/software/figtree/) software. Sample sequences are deposited in the GenBank database under accession numbers MT012231- MT012236.

Table 1. List of Sarocladium sp. isolates

\begin{tabular}{|c|c|c|c|c|c|}
\hline Field code & District & Province & Varieties origin & Sample code & Coordinates \\
\hline BN1 & Serang & Banten & Inpari 22 & SO12 & $6^{\circ} 13^{\prime} 18.1^{\prime \prime S} 106^{\circ} 07^{\prime} 27.3^{\prime \prime E}$ \\
\hline $\mathrm{BN} 2$ & & & Ciherang & SO16 & $6^{\circ} 07^{\prime} 49.9^{\prime \prime S} 106^{\circ} 12^{\prime} 32.7^{\prime \prime} \mathrm{E}$ \\
\hline $\mathrm{BN} 3$ & & & Inpari 22 & $\mathrm{SO} 2$ & $6^{\circ} 04^{\prime} 15.0^{\prime \prime} \mathrm{S} 106^{\circ} 12^{\prime} 42.0^{\prime \prime} \mathrm{E}$ \\
\hline JB1 & Karawang & West Java & Mekongga & SO1; SO4; SO11 & $6^{\circ} 15^{\prime} 12.5^{\prime \prime} \mathrm{S} 107^{\circ} 17^{\prime} 42.6^{\prime \prime} \mathrm{E}$ \\
\hline JB2 & Sumedang & & Ciherang & SO3; SO10; SO21 & $6^{\circ} 50^{\prime 2} 24.1^{\prime \prime S ~} 107^{\circ} 55^{\prime} 44.9^{\prime \prime} \mathrm{E}$ \\
\hline JB3 & & & IR 64 & SO15; SO20 & $6^{\circ} 49^{\prime} 17.7^{\prime \prime S} 107^{\circ} 55^{\prime} 16.3^{\prime \prime E}$ \\
\hline JB4 & & & Ciherang & SO14 & 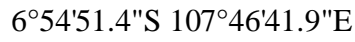 \\
\hline JB5 & Purwakarta & & Ciherang & $\mathrm{SO} 22$ & $6^{\circ} 35^{\prime} 00.3^{\prime \prime S} 107^{\circ} 26^{\prime} 07.8^{\prime \prime E}$ \\
\hline JT1 & Tegal & Central Java & Ciherang & SO9 & $6^{\circ} 54^{\prime} 54.6^{\prime \prime S} 109^{\circ} 07^{\prime} 32.9^{\prime \prime} \mathrm{E}$ \\
\hline JT2 & Pati & & IR 64 & SO5 & $6^{\circ} 51^{\prime 27.3 " S} 111^{\circ} 07^{\prime} 04.5^{\prime \prime} \mathrm{E}$ \\
\hline JT3 & Sukoharjo & & Mekongga & $\mathrm{SO} 23$ & 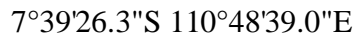 \\
\hline JM1 & Nganjuk & East Java & Ciherang & $\mathrm{SO} 24$ & $7^{\circ} 36^{\prime} 07.9^{\prime \prime S} 111^{\circ} 55^{\prime} 21.1^{\prime \prime E}$ \\
\hline JM2 & Jombang & & IR 64 & SO7 & $7^{\circ} 36^{\prime} 59.8^{\prime \prime S} 112^{\circ} 18^{\prime} 26.0^{\prime \prime} \mathrm{E}$ \\
\hline JM3 & Tulungagung & & Memberamo & SO13 & $8^{\circ} 05^{\prime} 09.1^{\prime \prime S} 111^{\circ} 50^{\prime} 20.5^{\prime \prime} \mathrm{E}$ \\
\hline JM4 & Gresik & & Memberamo & SO17 & $5^{\circ} 48^{\prime} 19.8^{\prime \prime S} 112^{\circ} 42^{\prime} 21.3^{\prime \prime E}$ \\
\hline BI1 & Badung & Bali & Ciherang & SO18 & $8^{\circ} 28^{\prime} 45.8^{\prime \prime} \mathrm{S} 115^{\circ} 11^{\prime} 14.5^{\prime \prime} \mathrm{E}$ \\
\hline BI2 & & & Ciherang & SO19 & $8^{\circ} 31^{\prime} 08.0^{\prime \prime S} 115^{\circ} 10^{\prime} 29.7^{\prime \prime E}$ \\
\hline $\mathrm{BI} 3$ & Tabanan & & Memberamo & SO6 & $8^{\circ} 30^{\prime} 25.8^{\prime \prime S} 115^{\circ} 07^{\prime} 58.5^{\prime \prime} \mathrm{E}$ \\
\hline SS1 & Gowa & South Sulawesi & Ciherang & SO8 & $5^{\circ} 17^{\prime} 47.4^{\prime \prime S} 119^{\circ} 27^{\prime} 06.5^{\prime \prime E}$ \\
\hline
\end{tabular}


Table 2. Phylogenetic reference sequences isolates used in this study

\begin{tabular}{|c|c|c|c|c|}
\hline Species & $\begin{array}{c}\text { Strain (original } \\
\text { identification) }\end{array}$ & Origin & $\begin{array}{c}\text { GenBank } \\
\text { acc. no. }\end{array}$ & Reference \\
\hline \multirow[t]{2}{*}{ Sarocladium bacillisporum } & CBS 212.79 & Insect, Romania & HG965002 & Giraldo et al. 2015 \\
\hline & CBS 388.67 & Soil, Netherlands & HG965003 & Giraldo et al. 2015 \\
\hline Sarocladium bactrocephalum & CBS $749.69^{\mathrm{T}}$ & Ustilago sp. Canada & HG965006 & Giraldo et al. 2015 \\
\hline Sarocladium bifurcatum & CBS 383.73 & Dead stem of bamboo, India & HG965008 & Giraldo et al. 2015 \\
\hline Sarocladium gamsii & CBS 425.73 & Dead petiole of Pandanus lerum, Sri Lanka & HG965014 & Giraldo et al. 2015 \\
\hline \multirow[t]{2}{*}{ Sarocladium glaucum } & CBS 382.73 & Dead stem of bamboo, India & HG965018 & Giraldo et al. 2015 \\
\hline & CBS 100350 & Dead stem of bamboo, Japan & HG965020 & Giraldo et al. 2015 \\
\hline Sarocladium hominis & UTHSC 02-2564 & Leg, USA & HG965011 & Giraldo et al., 2015 \\
\hline \multirow[t]{2}{*}{ Sarocladium implicatum } & CBS 397.70A & Saccharum officinarum, Jamaica & HG965021 & Giraldo et al. 2015 \\
\hline & CBS $959.72^{\mathrm{NT}}$ & Dessert soil, Egypt & HG965023 & Giraldo et al. 2015 \\
\hline Sarocladium ochraceum & CBS $428.67^{\mathrm{T}}$ & Zea mays, Kenya & HG965025 & Giraldo et al. 2015 \\
\hline \multirow[t]{4}{*}{ Sarocladium oryzae } & CBS $180.74^{\mathrm{ET}}$ & Oryza sativa, India & HG965026 & Giraldo et al. 2015 \\
\hline & CBS 399.73 & Oryza sativa, India & HG965027 & Giraldo et al. 2015 \\
\hline & CBS 414.81 & Oryza sativa, Nigeria & HG965028 & Giraldo et al. 2015 \\
\hline & CBS 361.75 & Oryza sativa, Kenya & AY566993 & Bills et al. 2014 \\
\hline Sarocladium pseudostrictum & UTHSC $02-1892^{\mathrm{T}}$ & Sputum, USA & HG965029 & Giraldo et al. 2015 \\
\hline Sarocladium strictum & CBS $346.70^{\mathrm{T}}$ & Triticum aestivum, Germany & FN691453 & Giraldo et al. 2015 \\
\hline Sarocladium subulatum & MUCL $9939^{\mathrm{T}}$ & Soil, Egypt & HG965031 & Giraldo et al. 2015 \\
\hline \multirow{3}{*}{ Sarocladium summerbellii } & CBS 200.84 & Water in air moistener, Netherlands & HG965033 & Giraldo et al. 2015 \\
\hline & CBS 797.69 & Decaying leaf of Canna indica, Netherlands & HG965035 & Giraldo et al. 2015 \\
\hline & CBS 951.72 & Agricultural soil, Netherlands & HG965037 & Giraldo et al. 2015 \\
\hline \multirow{8}{*}{$\begin{array}{l}\text { Sarociadium terricola } \\
\text { Sarocladium zeae } \\
\text { Sarocladium sp. }(= \\
\text { Sarocladium oryzae) }\end{array}$} & MUCL 12011 & Decaying leaf of Milleta launentii, D.R. Congo & HG965039 & Giraldo et al. 2015 \\
\hline & CBS $800.69^{\mathrm{T}}$ & Zea mays stalk, USA & FN691451 & Giraldo et al. 2015 \\
\hline & SO 2 & Oryza sativa, Serang, Banten, Indonesia & MT012231 & This study \\
\hline & SO 3 & Oryza sativa, Sumedang, West Java, Indonesia & MT012232 & This study \\
\hline & SO 5 & Oryza sativa, Pati, Central Java, Indonesia & МT012234 & This study \\
\hline & SO 8 & Oriza sativa, Gowa, South Sulawesi, Indonesia & MT012236 & This study \\
\hline & SO 11 & Oryza sativa, Karawang, West Java, Indonesia & MT012233 & This study \\
\hline & SO 13 & Oryza sativa, Tulungagung, East Java, Indonesia & MT012235 & This study \\
\hline Acremonium curvulum & CBS $430.66^{\mathrm{T}}$ & Wheatfield soil, Germany & HE608638 & Giraldo et al. 2012 \\
\hline
\end{tabular}

Note: ET: Epitype strain; NT: Neotype strain ; T: type strain

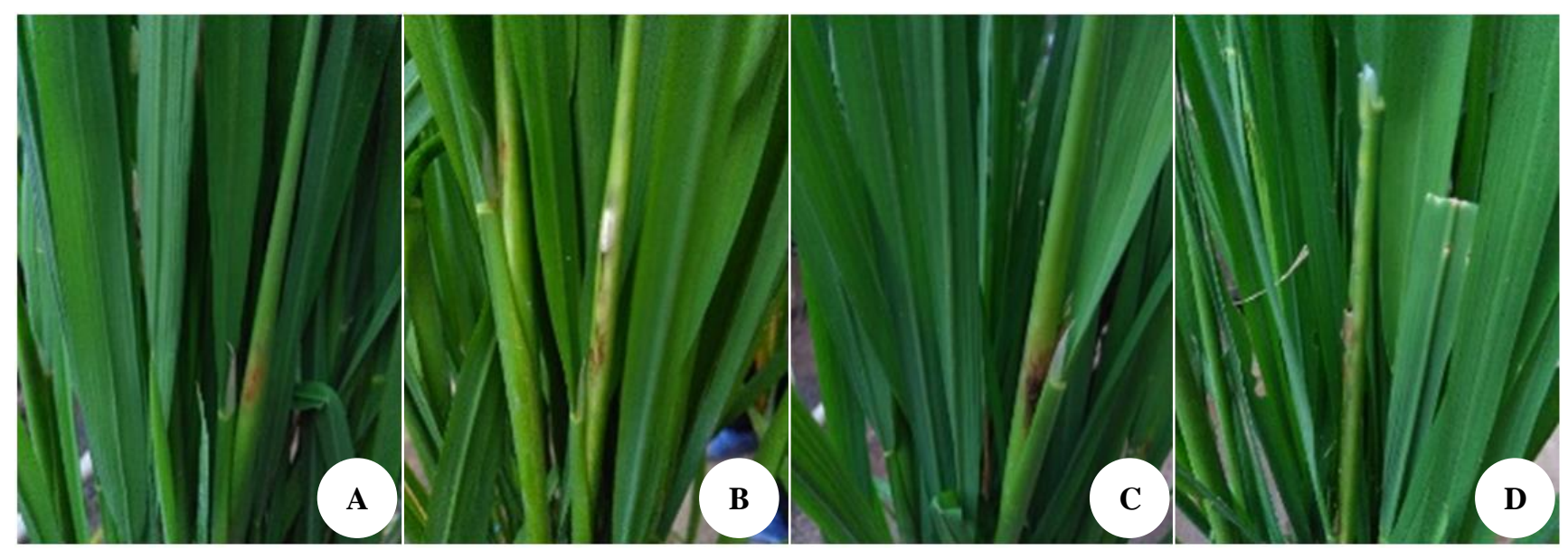

Figure 2. Pathogenicity test of Sarocladium sp. 7DAI. Symptomatic leaf sheath, isolate SO2 (A); SO3(B); SO8 (C); control (D) 


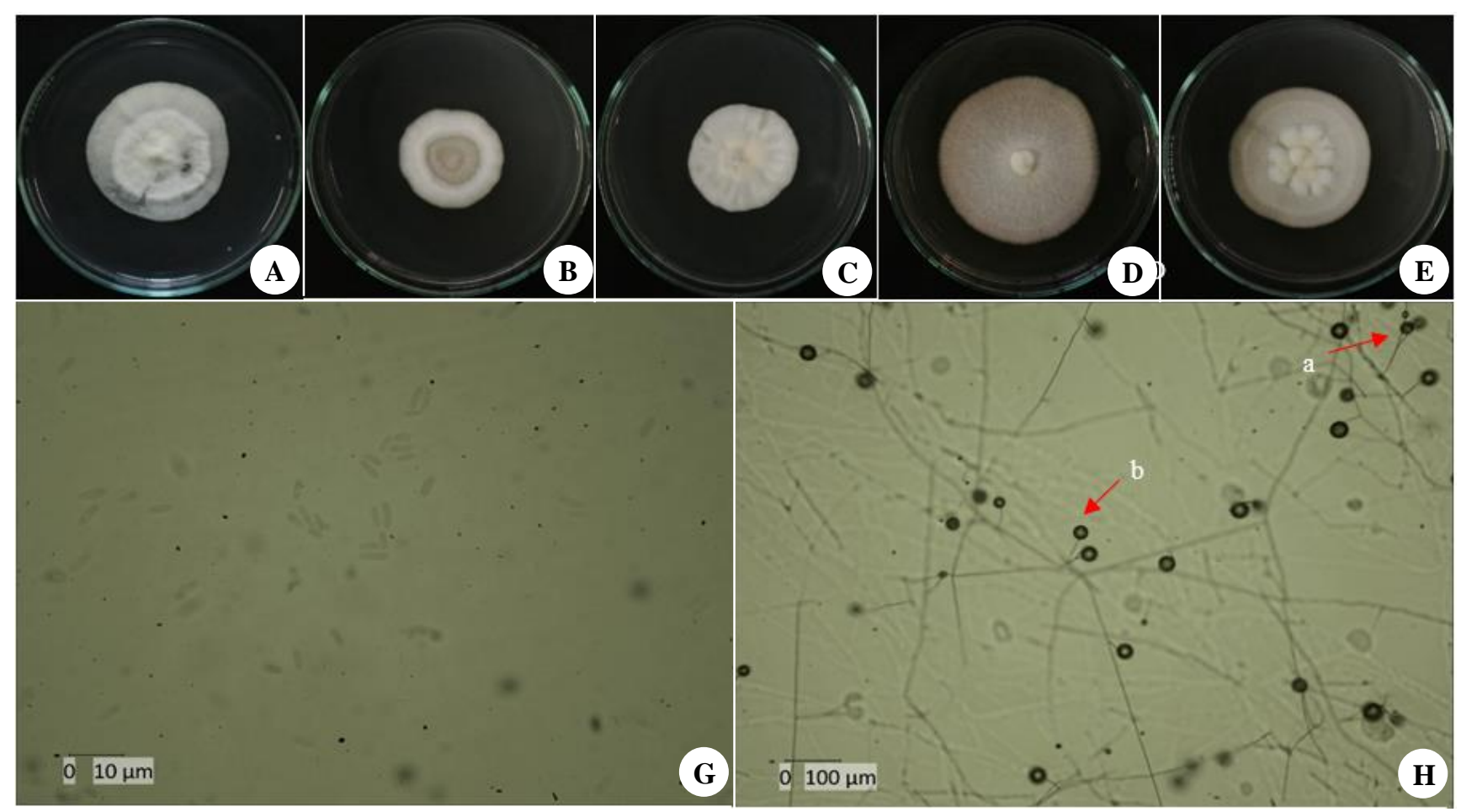

Figure 3. Morphology of Sarocladium sp.: cultural colony morphology isolate SO 2 (A); SO 3 (B); SO 5 (C); SO 8 (D); SO 13 (E); $14 \mathrm{~d}$ completely dark on PDA; Conidia of Sarocladium sp. (G); Conidia aerial mycelium presentation branched conidiophore (H.a); slimy head conidia formed (H.b)

\section{RESULTS AND DISCUSSION}

Pathogenicity test and culture morphology characteristics

Sheath rot disease was found in the rice field at the sampling site. A total of twenty-four Sarocladium sp. isolates were collected from nineteen sampling locations in six provinces in Indonesia (Table 1). Artificial inoculation of Ciherang rice variety without wounding, showed that sheath necrosis occurred in all Sarocladium sp. isolates which varied in the disease severity index range from 300500 (data not shown). Necrosis were first noted within 4872 hours after inoculation varied in each isolates (data not shown). DSI index was affected by the level virulence of pathogen infection and host response. Pathogens that have a high level of virulence in susceptible hosts will produce high DSI values and a faster time for symptoms to appear. The symptoms obtained are in accordance to Nair (1976); Ou (1985) and Mvuyekure et al. (2017), where the rot starts with irregular small spots and brown margins and occurs on the leaf sheaths enclosing the young panicles. The spot then enlarges and changes color to reddish-brown and the stems will rot. Symptoms caused causes panicles changes color to blackish-brown and not completely exerted. The control plants remained asymptomatic (Figure 2).

Morphological characteristics for all Sarocladium sp. was observed. Sarocladium sp. isolates grows slowly (about $1.9 \mathrm{~mm} / \mathrm{r} /$ day) on PDA at $25^{\circ} \mathrm{C}$ in the dark. Colony characteristics of Sarocladium sp. were cottony, produces mycelia color varies from white to light yellow, sometimes turn into pale orange with age (Figure 3) and pale orange color of reverse views. Vegetative hyphae of Sarocladium sp. are septate, hyaline, smooth and thin-walled. Conidiphores of Sarocladium sp. are hyaline, smooth-walled and can be simple or branched. Conidia are cylindrical, hyaline and aseptate, $1.6-4.8 \mu \mathrm{m} \times 0.6-1.7 \mu \mathrm{m}$ in size and arranged in slimy heads (Figure 3). Chlamydospores not observed. These characters are similar to morphological features of $S$. oryzae, which is slow growth fungi (Bigirimana et al. 2015), has white, orange-white colonies on PDA at $25^{\circ} \mathrm{C}$ with the formation of conidia in slimy heads and not produce chlamydospores (Giraldo et al. 2015). In addition to $S$. oryzae, which has an important role in causing sheath rot disease, another member of the genus Sarocladium has a role in causing disease in rice is Sarocladium synense that causing rice purple sheath disease in China (Giraldo et al. 2015). However, S. oryzae is a common pathogen in rice and in several species of bamboo (Bambusa balcooa, Bambusa tulda, Bambusa vulgaris) (Boa and Brady 1987).

Morphological observation of fungi is less credible because there are several fungi that cannot be distinguished morphologically. Morphological data are not enough as a basis for determining a species because it can lead to improper identification. Implementation of molecular fungal identification needs to be done to identify fungal species through phylogenetic analysis to get correct results. However, morphological observation of fungi can be used as supporting data for the characteristics of a fungus (Sarwar et al. 2019). Fungal isolates that based on morphological identified as Sarocladium sp., DNA sequencing were also carried out by ITS rDNA gene sequence to correctly identify species. 


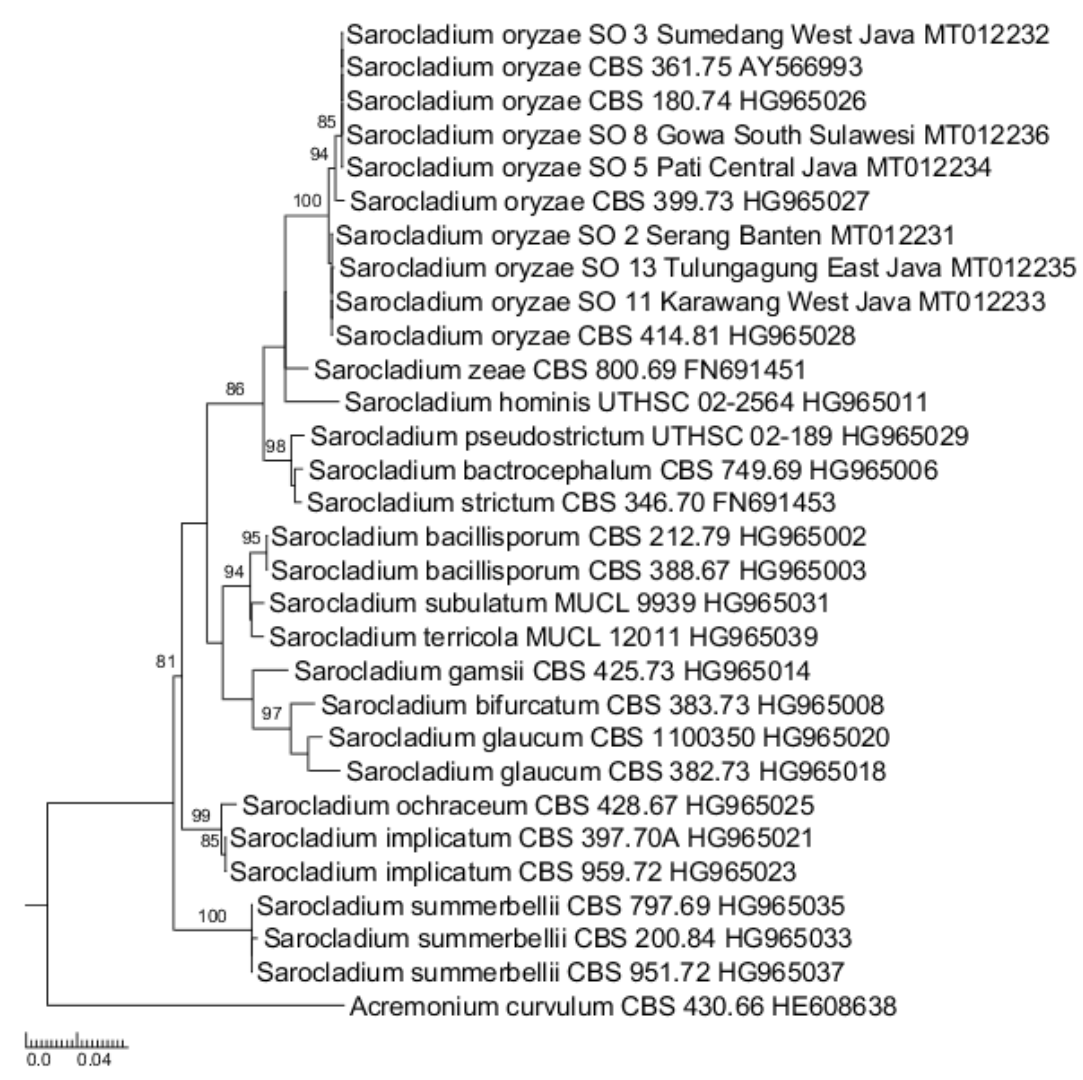

Figure 4. Maximum-likelihood phylogenetic tree based on comparative ITS rDNA gene sequence analysis of Sarocladium sp. showing the phylogenetic affiliation of Sarocladium oryzae strains. Acremonium curvulum CBS 430.66 HE608638 was used as outgroup

\section{Phylogenetic analysis}

The ITS rDNA region is a marker for identification of fungi with high probability (Schoch et al. 2012). In this research, six representative Sarocladium sp. isolates selected for molecular identification by ITS rDNA gene sequencing. The ITS rDNA gene sequences of six Sarocladium sp. were successfully identified by using BLASTn based on GenBank databases. The phylogenetic analysis of six Sarocladium sp. construct with ITS rDNA gene sequence by reference sequence (Table 2). Based on Maximum-Likelihood (ML) phylogenetic analysis, six Sarocladium sp. isolates were identified as $S$. oryzae and were close to references isolates (Figure 4).

It is the first report about the existence of sheath rot disease in various rice fields in Indonesia. Our result showed that one of the major fungal pathogen of sheath rot disease in Indonesia caused by $S$. oryzae. It is the first report for the existence of $S$. oryzae in various rice fields in Indonesia. These findings are important information about $S$. oryzae in Indonesia. The presence of $S$. oryzae in countries around Indonesia such as Malaysia, Brunei Darussalam, the Philippines and Thailand has been reported, but there have been no more detailed reports (EPPO 2014).

The further studies about developing control measures to prevent the disease on the field through the implementation of biological control of the pathogen to prevent the disease epidemic on rice are necessary. Sheath rot has become an important disease in rice plants (Bigirimana et al. 2015). The occurrence and severity index of sheath rot disease are affected by external factors such as environmental conditions and farming practices, and internal factors such as varietal susceptibility (Pramunadipta et al. 2017). More attention must be given to this disease to prevent the epidemic and the spread of disease to the other rice production field to decreasing yield loss that can maybe happen in future.

\section{ACKNOWLEDGEMENTS}

This study has been funded by Ministry of Research, Technology and Higher Education of the Republic of Indonesia by PMDSU number 2964/UN1.DITLIT/DITLIT/LT/2019.

\section{REFERENCES}

Amin KS, Sharma BD, Das CR. 1974. Occurrence in India of sheath rot of rice caused by Acrocylindrium. Plant Dis Rep 58: 358-360.

Ayyadurai N, Kirubakaran SI, Srisha S, Sakthivel N. 2005. Biological and molecular variability of Sarocladium oryzae, the sheath rot pathogen of rice (Oryza sativa L.). Curr Microbiol 50: 319-323. 
Balgude YS, Kshirsagar CR, Gaikwad AP. 2019. Evaluation on the efficacy of modern fungicides against blast and sheath rot of rice. Int J Curr Microbiol Appl Sci 8: 83-88.

Bigirimana VP, Hua GKH, Nyamangyoku OI, Höfte M. 2015. Rice Sheath Rot: An Emerging Ubiquitous Destructive Disease Complex. Front Plant Sci 6: 1-16.

Bills GF, Platas G, Gams W. 2004. Conspecificity of the cerulenin and helvolic acid producing "Cephalosporium caerulens", and the hypocrealean fungus Sarocladium oryzae. Mycol Res 108: 12911300 .

Boa ER, Brady BL. 1987. Sarocladium oryzae associated with blight of Bambusa species in Bangladesh. Trans B Mycol Soc 89: 161-166.

BPS. 2020. Harvested Area, Productivity, and Production of Paddy by Province, 2018-2019. https://www.bps.go.id/dynamictable/2019/04/15/1608/luas-panenproduksi-dan-produktivitas-padi-menurut-provinsi-2018-2019.html.

Bridge PD, Hawksworth DL, Kavishe DF, Farnell PA. 1989. A revision of the species concept in Sarocladium, the causal agent of sheath-rot in rice and bamboo blight, based on biochemical and morphometric analyses. Plant Pathol 38: 239-245.

Chowdhury MTI, Mian MSM, Mia MAT, Rafi MY, Latif MA. 2015 Agro-ecological variations of sheath rot disease of rice caused by Sarocladium oryzae and DNA fingerprinting of the pathogen's population structure. Genet Mol Res 14: 18140-18152.

Desjardins AE, Manandhar KH, Plattner RD, Manandhar GG, Poling SM, Maragos CM. 2000. Fusarium species from Nepalese rice and production of mycotoxins and gibberellic acid by selected species. Appl Environ Microbiol 66: 1020-1025.

EPPO. 2014. EPPO Global database (available online). Paris, France: EPPO. https://gd.eppo.int/.

Garcia DM, Diaz CH, Artiles YC, Ramos RA, Rubi JA. 2003. Characterization of the proteinases secreted by Sarocladium oryzae. Biotecnología Aplicada 20: 170-172.

Ghosh MK, Amudha R, Jayachandran S, Sakthivel N. 2002. Detection and quantification of phytotoxic metabolites of Sarocladium oryzae in sheath rot-infected grains of rice. Lett Appl Microbiol 34: 398-401.

Giraldo A, Gené J, Cano J, De Hoog S, Guarro J. 2012- Two new species of Acremonium from Spanish soils. Mycologia 104: 1456-1465.

Giraldo A, Gené J, Sutton DA, Madrid H, De Hoog GS, Cano J, Decock C, Crous PW, Guarro J. 2015. Phylogeny of Sarocladium (Hypocreales). Persoonia 34: 10-24.

Gnanamanickam SS, Mew TW. 1991. Interactions between Sarocladium oryzae and stem attacking fungal pathogens of rice. Plant Soil 138: 213-219.

Gopalakrishnan C, Kamalakannan A, Valluvaparidasan V. 2010. Effect of seed-borne Sarocladium oryzae, the incitant of rice sheath rot on rice seed quality. J Plant Prot Res 50: 98-102.

Hittalmani S, Mahesh HB, Mahadevaiah C, Prasannakumar MK. 2016. De novo genome assembly and annotation of rice sheath rot fungus Sarocladium oryzae reveals genes involved in helvolic acid and cerulenin biosynthesis pathways. BMC Genomics 17: 1-13.

Kornerup A, Wanscher JH. 1978. Methuen handbook of colour. 3rd ed. Eyre Methuen, London.

Kumar S, Stecher G, Li M, Knyaz C, Tamura K. 2018. MEGA X: molecular evolutionary genetics analysis across computing platforms. Mol Biol Evol Soc 35: 1547-1549.

Liu XB, Guo ZK, Huang GX. 2017. Sarocladium brachiariae sp. nov., an endophytic fungus isolated from Brachiaria briz. Mycosphere 8: 827834.

Mathur SC. 1981. Observations on diseases of dryland rice in Brazil. In: International Rice Research Newsletter. IRRI, Manila, Philippines.
Mau YS, Markus JER, Oematan SS, Ndiwa ASS, Handoko DD, Nasution A, Makbul K. 2017. Genetic diversity of red and black upland rice accessions from East Nusa Tenggara, Indonesia as revealed by agromorphological characters. Biodiversitas 18: 197-211.

Mew TW, Gonzales P. 2002. A Handbook of Rice Seedborne Fungi. Science Publishers, Philippines.

Mvuyekure SM, Sibiya J, Derera J, Nzungize J, Nkima G. 2017. Genetic analysis of mechanisms associated with inheritance of resistance to sheath rot of rice. Plant Breed 136: 509-515.

Nair R. 1976. Incidence of sheath rot in rice a potential problem for Sambalpur, Orissa. In: International Rice Research Notes. IRRI, Manila, Philippines.

Narayanasamy P, Viswanathan R. 1990. A new scoring system for sheath rot of rice. Madras Agric J 77: 256-257.

Ou SH. 1985. Rice Diseases. 2nd ed. The Cambrian News, UK

Park JW, Choi SY, Hwang HJ, Kim YB. 2005. Fungal mycoflora and mycotoxins in Korean polished rice destined for humans. Int J Food Microbiol 103: 305-314.

Pearce DA, Bridge PD, Hawksworth DL. 2001. Species concept in Sarocladium, the causal agent in sheath rot in rice and bamboo blight. In: Major Fungal Diseases of Rice. Springer, Dordrecht

Pramunadipta S, Widiastuti A, Priyatmojo A. 2017. Environmental Factors Affecting the Severity of Sheath Rot Disease (Sarocladium oryzae and Fusarium spp.) on Paddy. Abstract. 2nd International Conference of Tropical Agriculture. Sustainable Tropical Agriculture Symposium. Yogyakarta, Indonesia, 26- 27 October 2017.

Sakthivel N. 2001. Sheath rot disease of rice: current status and control strategies. In: Major Fungal Diseases of Rice. Springer, Dordrecht.

Sarangi SK, Maiji B, Mahanta KK, Digar S, Burman D, Mandal S, Mandal UK, Sharma PC, Mainuddin M, Bell RW. 2019. Alternate Kharif rice crop establishment methods and medium duration varieties to enable cropping system intensification in coastal saline regions. J Indian Soc Coast Agric Res 37: 115-122.

Sarwar S, Firdous Q, Khalid AN. 2019. Importance of molecular and phylogenetic analyses for identification of basidiomycetes. In: Recent Advances in Phylogenetics. IntechOpen, UK.

Schoch CL, Seifert KA, Huhndorf S, Robert V, Spouge JL, Levesque CA, Chen W. Fungal Barcoding C. 2012. Nuclear ribosomal internal transcribed spacer (ITS) region as a universal DNA barcode marker for Fungi. Proc Nat Acad Sci 109: 6241-6246.

Shamsi S, Chowdhury P. 2016. In vitro evaluation of fungicides and some plant extracts against rice sheath rot pathogen Sarocladium oryzae. Bangladesh J Sci Res 29: 47-54.

Srinivasachary SH, Kumar KG, Shashidhar HE, Vaishali MG. 2002. Identification of quantitative trait loci associated with sheath rot resistance (Sarocladium oryzae) and panicle exsertion in rice (Oryza sativa L.). Curr Sci 82: 133-135.

Suga H, Karugia GW, Ward T, Gale LR, Tomimura K, Nakajima T, Miyasaka A, Koizumi S, Kageyama K, Hyakumachi M. 2008. Molecular characterization of Fusarium graminearum species complex in Japan. Phytopathology 98: 159-166.

Tschen J, Chen L, Hsieh S, Wu T. 1997. Isolation and phytotoxic effects of helvolic acid from plant pathogenic fungus Sarocladium oryzae. Bot Bull Acad Sin 38: 251-256.

White TJ, Bruns T, Lee S, Taylor J. 1990. Amplification and direct sequencing of fungal ribosomal RNA genes for phylogenetics. In: PCR Protocols: A Guide to Methods and Applications. Academic Press, Inc., United State.

Zhang J, Pan Y, Li Y, Ren T, Cong R, Lu J, Li X. 2019. Low grain sink activity imposed by potassium deficiency aggravates loss in quality of rice (Oryza sativa L.) infected with natural sheath rot disease. J Cereal Sci 87: 31-38. 